\title{
FENOMENA QUASI BROKEN HOME DALAM KELUARGA PEKEBUN
}

\section{Podi Sastra Pramana Putra}

\author{
Lembaga Konsultasi dan Bantuan Hukum IAIN Bengkulu \\ Jl. Raden Fatah Pagar Dewa Bengkulu \\ Email: Podysastra95@gmail.com
}

\begin{abstract}
The quasi broken home phenomenon in the families of planters can be seen that, this family resembles the Broken Home family, where the relationship between parents and children does not work well. However, the parents are still intact. In addition, parents often leave children. This is caused by several factors, namely parents are busy with work so they do not have time and time to guide their children. Sometimes quasi broken home is caused by parents leaving children without news. The impact of quasi broken home on children's behavior is: children often go home late at night, skip school, fight, deny parents to even get drunk.
\end{abstract}

Keywords: Phenomenon, Quasi Broken Home, Farmers.

\begin{abstract}
Abstrak: Fenomena quasi broken home dalam keluarga pekebun dapat dilihat bahwa, keluarga ini menyerupai keluarga Broken Home, dimana hubungan antara orang tua dan anak tidak berjalan dengan baik. Namun, orang tua masih utuh. Di samping itu, orang tua lebih sering meninggalkan anak. Hal ini disebabkan oleh beberapa faktor yaitu orang tua sibuk dengan pekerjaan sehingga tidak memiliki waktu luang dan waktu untuk membimbing anak. Adakalanya quasi broken home disebabkan oleh orang tua meninggalkan anak tanpa berita. Dampak quasi broken home pada perilaku anak yaitu: anak sering pulang larut malam, bolos sekolah, berkelahi, membantah orang tua bahkan sampai mabuk-mabukan.
\end{abstract}

Kata kunci: Fenomena, Quasi Broken Home, Keluarga Pekebun. 
AL-IMARAH: Jurnal Pemerintahan dan Politik Islam Vol. 3, No. 2, 2018

\section{Pendahuluan}

Keluarga merupakan lingkungan sosial yang sangat dekat hubungannya dengan seseorang. ${ }^{1}$ Di keluarga itu seseorang dibesarkan, bertempat tinggal, berinteraksi satu dengan yang lain, dibentuknya nilai-nilai, pola pemikiran, dan kebiasaannya. Keluarga juga berfungsi sebagai seleksi segenap budaya luar, dan mediasi hubungan anak dengan lingkungannya. Keluarga yang lengkap dan fungsional akan dapat meningkatkan kesehatan mental para anggota keluarganya, dan kemungkinan dapat meningkatkan ketahanan para anggota keluarganya dari adanya gangguan-gangguan mental dan ketidak stabilan emosional para anggotanya. ${ }^{2}$

Sejak anak-anak dilahirkan di dunia ketergantungan anak-anak terhadap kedua orang tua sangat besar. Dengan penuh kasih sayang kedua orang tuanya memenuhi kebutuhan-kebutuhan anak-anaknya yang masih belum berdaya. Ditutupi badannya dengan pakaian dan selimut agar tidak kedinginan atau disengat semut atau insektan lainnya. Jika kurang sehat segera diperiksakan ke dokter, tidak dihiraukan siang ataupun malam, sedang hujan lebat atau pun panas kering kerontang, asal anak sembuh dan sehat kembali upaya apapun yang dirasakan berguna

\footnotetext{
1 Moeljono Notosoedirdjo dan Latipun, Kesehatan Mental Konsep dan Peranan, (Malang: Universitas Muhammadiyah, 2005), h. 107.

${ }^{2}$ Moeljono Notosoedirdjo dan Latipun, Kesehatan Mental, h. 107.

tentu akan dilaksanakan. ${ }^{3}$ Jika dianalisa kasih sayang pada masa anak, didapati bahwa yang pertama kali menjadi perhatian anak adalah orang tuanya dan orang-orang yang memperhatikannya dalam keluarga, sebabnya adalah karena dunia anak terbatas kepada dunia keluarga itu. ${ }^{4}$ Akan tetapi setelah si anak bertumbuh dan bertambah besar serta masuk ke masa remaja, timbul dalam dirinya kebutuhan untuk berdiri sendiri. Hal itu disebabkan oleh karena hubungannya diluar semakin luas, dan ia mulai membentuk teman baru dengan teman-teman sebaya. Demikian kuatnya persaudaraan, sehingga sangat berpengaruh pada jiwa remaja. Berapa banyaknya remaja yang mengalami kegoncangan dan keputusasaan karena gagal dalam mendapatkan penerimaan teman terhadap dirinya, atau karena perbedaan dirinya dari temannya. ${ }^{5}$ Oleh karena itu dapat dilihat bahwa remaja sangat memerlukan kasih sayang temannya sepermainan dan sekolah, dari waktu ke waktu remaja ingin merasa bahwa orang lain menyayanginya.

Anak sebagai bagian dari keluarga memerlukan pemeliharaan dan perlindungan khusus dan tergantung pada bantuan dan pertolongan orang dewasa, terutama pada tahun-tahun pertama kehidupannya. Terlebih dalam pemenuhan hak-haknya, seorang anak

${ }^{3}$ Hasan Basri, Keluarga Sakinah Tinjauan Psikologi dan Agama, (Yogyakarta: Pustaka Pelajar, 2004), h. 89

4 Musthafa Fahmi, Kesehatan Jiwa dalam Keluarga, Sekolah, dan Masyarakat, (Jakarta: Bulan Bintang, 1977), h. 59.

${ }^{5}$ Musthafa Fahmi, Kesehatan..., h. 59. 
tidak biasa melakukannya sendiri disebabkan kemampuan dan pengalamannya yang masih terbatas, orang dewasa, khususnya orang tua memegang peranan penting dalam memenuhi hak-hak anak.

Berdasarkan observasi awal yang dilakukan peneliti di Kelurahan Pematang Gubernur Kecamatan Muara Bangkahulu Kota Bengkulu, diketahui banyaknya orang tua yang sering meninggalkan anak untuk bekerja dalam waktu yang relatif lama. Kemudian, peneliti melihat terdapat beberapa anak yang tingkah lakunya tidak sesuai dengan anak pada umumnya. Tingkah laku mereka cenderung negatif. Hal ini terlihat dari kehidupan seharihari mereka yang terlalu bebas dan melakukan sesuatu dengan semaunya. Peneliti juga melihat adanya kelakuan-kelakuan buruk dari anak-anak ini seperti menonton film porno bahkan terjerumus pada seks bebas. Di samping itu mereka juga sering melakukan penyimpangan-penyimpangan seperti berpacaran akhirnya mereka tidak mementingkan sekolah, sering tidak masuk ke sekolah bahkan di sekolah mereka mendapatkan nilai yang tidak memuaskan.

Dari pengamatan tentang hal ini, peneliti berasumsi bahwa dalam hal ini ada salah satu bentuk indikasi seperti keluarga Quasi Broken Home, ini disebabkan oleh tidak terpenuhinya hak-hak anak dalam keluarga, orang tua terlalu sibuk dengan aktivitas dan pekerjaannya masing-masing sehingga melupakan hak-hak yang seharusnya mereka berikan untuk anakanaknya, sehingga hal tersebut membuat anak melakukan hal-hal negatif.

\section{Keluarga}

Yang disebut dengan keluarga adalah orang-orang yang secara terus menerus atau sering tinggal bersama si anak, seperti ayah, ibu, kakek, nenek, saudara laki-laki, saudara perempuan dan bahkan pembantu rumah tangga. ${ }^{6}$ Di antara mereka, ayah dan ibu, disebabkan mempunyai tanggung jawab menjaga dan memelihara si anak dan yang menyebabkan si anak terlahir kedunia, mempunyai peranan yang sangat penting dan kewajiban yang lebih besar bagi pendidikan si anak. Keluarga dalam bentuk yang paling sederhana dan asasi terdiri atas laki-laki dan perempuan, hidup dalam ikatan perkawinan, beserta anak atau anak-anaknya dibawah umur, yang diakui oleh anggota masyarakatnya. ${ }^{7}$

Keluarga merupakan sel pertama dan cikal bakal bangunan masyarakat. Hal itu tidaklah mengherankan karena masyarakat terbentuk dari sekumpulan keluarga. Oleh karena itu setiap pribadi harus memahami hakikat perniakahan. Yaitu peralihan dari tanggung jawab pribadi ke tanggung jawab bersama. Pernikahan bisa menjadi sumber kerusakan bagi masyarakat manakala pernikahan itu melahirkan pribadi-pribadi

\footnotetext{
${ }^{6}$ Ibrahim Amini, Agar..., h. 107

7 Kaelany HD, Islam dan Aspek-Aspek Kemasyarakatan, (Jakarta: Bumi Aksara, 2000), h. 162
} 
AL-IMARAH: Jurnal Pemerintahan dan Politik Islam Vol. 3, No. 2, 2018

yang tidak baik, yang tidak mendapat pendidikan yang baik, dan tidak mendapatkan perhatian yang semestinya. Dan keluarga juga bisa menjadi sumber perbaikan dan perubahan dalam masyarakat manakala pernikahan itu melahirkan pribadi-pribadi yang baik, yang memiliki bekal wawasan dan keilmuan. ${ }^{8}$

\section{Tujuan Pembentukan Keluarga}

Tujuan dasar pembentukan keluarga adalah: ${ }^{9}$

a) Keluarga merupakan unit dasar yang memiliki pengaruh kuat terhadap perkembangan individu.

b) Keluarga sebagai perantara bagi kebutuhan dan harapan anggota keluarga dengan kebutuhan dan tuntunan masyarakat.

c) Keluarga berfungsi untuk memenuhi kebutuhan-kebutuhan anggota keluarga dengan menstabilkan kebutuhan kasih sayang, sosio-ekonomi dan kebutuhan seksual.

d) Keluarga memiliki pengaruh yang penting terhadap pembentukkan identitas seseorang individu dan perasaan harga diri.

\section{Macam-macam Keluarga}

${ }^{8}$ Sobri Mersi Al-Faqi, Solusi Problematika Rumah Tangga Modern, (Surabaya: Sukses Publishing, 2015), h. 20-21.

${ }^{9}$ Sulistiyo Andarmoyo, Keperawatan Keluarga (Konsep Teori, Proses dan Praktik keperawatan), (Yogyakarta: Graha Ilmu), h. 5.
Pembagian tipe atau bentuk keluarga menurut Anderson carter, yaitu: ${ }^{10}$

a. Keluarga inti (nuclear family), yaitu keluarga yang terdiri dari ayah, ibu dan anak-anak.

b. Keluarga besar (extended family), yaitu keluarga inti ditambah dengan sanak saudara, nenek, kakek, keponakan, sepupu, paman, bibi dan sebagainya.

c. Keluarga berantai (serial family), yaitu keluarga ynag terdiri atas wanita dan pria yang menikah lebih dari satu kali dan merupakan satu keluarga inti.

d. Keluarga duda atau janda (single family), yaitu keluarga ini terjadi karena adanya perceraian atau kematian.

e. Keluarga berkomposisi yaitu keluarga yang perkawinannya berpoligami dan hidup secara bersama-sama.

f. Keluarga kabitas, yaitu dua orang menjadi satu tanpa pernikahan tetapi membentuk satu keluarga.

\section{Broken Home}

Ada banyak permasalahan kelurga yang saat ini menunjukkan bagaimana tidak kuatnya lagi ikatan batin maupun sosial dalam

${ }^{10}$ Nasrul Effendi, Dasar-dasar..., h. 34-35. 
keluarga yang sangat diagung-agungkan. ${ }^{11}$ Broken home merupakan kondisi di mana keluarga yang terdiri dari ayah, ibu dan anak tidak lagi bersatu. Arti broken home dalam bahasa Indonesia adalah perpecahan dalam keluarga. Broken home dapat juga diartikan dengan kondisi keluarga yang tidak harmonis dan tidak berjalan layaknya keluarga yang rukun, damai dan sejahtera karena sering terjadi keributan serta perselisihan yang menyebabkan perselisihan. ${ }^{12}$

Dalam broken home pada prinsipnya struktur keluarga tersebut sudah tidak lengkap lagi yang disebabkan adanya hal-hal: ${ }^{13}$

a) Salah satu kedua orang tua atau kedua-duanya meninggal dunia.

b) Perceraian orang tua.

c) Salah satu kedua orang tua atau kedua-duanya "tidak hadir" secara kontinyu dalam tenggang waktu yang cukup lama.

Menurut Romli Atmasasmita dalam buku problema kenakalan anak, menjelaskan bahwa ciri-ciri keluarga broken home adalah sebagai berikut: ${ }^{14}$

11 Muhammad Rifa'I, Sosiologi Pendidikan, (Jakarta: Ar-Ruzz Media, 2011), h. 237.

${ }^{12}$ Santrock, Life Span Defelopment, terjemahan oleh Juda Damanik, Ahmad Chusairi, (Jakarta: Erlangga 2002), h. 156

13 Sudarsono, Kenakalan Remaja, (Jakarta: Rineka Cipta, 2008), h. 125.

${ }^{14}$ Romli Atmasasmita, Problema Kenakalan Anak-anak atau Remaja, (Bandung: CV. Armico, 1984), h. 57. a. Adanya kematian dari salah satu orang tua

b. Adanya perceraian

c. Pisah rumah (scheiding van tefel en bed)

Dari ciri-ciri yang dikemukakan diatas Y. Bambang Mulyono menambahkan ciri-ciri keluarga broken home adalah sebagai berikut: ${ }^{15}$

a. Unit keluarga yang tidak lengkap dikarenakan hubungan di luar pernikahan.

b. Tidak adanya komunikasi yang sehat dalam keluarga (empty shell family).

c. Adanya ketidak cocokan antara pihak orang tua dan senantiasa berada dalam suasana perselisihan.

\section{Quasi Broken Home}

Quasi dalam Kamus Populer Bahasa Inggris berarti pura-pura, tak benar ${ }^{16}$, dan ada juga yang berpendapat bahwa quasi berarti semu. Keadaan keluarga yang tidak normal bukan hanya terjadi pada broken home, akan tetapi dalam masyarakat modern sering pula terjadi suatu gejala adanya quasi broken home (broken home semu), ${ }^{17}$ ialah kedua orang tuanya masih utuh, tetapi karena masingmasing anggota keluarga (ayah dan ibu)

${ }^{15}$ Romli Atmasasmita, Problema ..., h. 27.

16 Achmad Fanani, Kamus Populer InggrisIndonesia,Indonesia-Inggris, (Jogjakarta: Literindo, 2016), h. 321.

${ }^{17}$ Sudarsono, Kenakalan ... h. 126. 
AL-IMARAH: Jurnal Pemerintahan dan Politik Islam Vol. 3, No. 2, 2018

mempunyai kesibukan masing-masing sehingga orang tua tidak sempat memberikan perhatiannya terhadap pendidikan anakanaknya. Dalam kaitannya Bimo Walgito menjabarkan lebih jelas lagi bahwa: tidak jarang orang tua tidak dapat bertemu dengan anak-anaknya. Orang tua kembali dari kerja, anak-anak sudah bermain di luar, anak pulang orang tua sudah pergi lagi, orang tua datang anak-anak sudah tidur, dan seterusnya. Keadaan yang semacam ini jelas tidak menguntungkan perkembangan anak.

Sedangkan definisi quasi broken home menurut Gerungan ialah apabila di dalam keluarga yang mana orang tua masih utuh, akan tetapi ayah dan ibu jarang pulang ke rumah yang disebabkan tugas atau hal-hal lain sehingga harus meninggalkan anak-anaknya dan hal ini terjadi secara berulang-ulang. Sehingga mengakibatkan interaksi dalam keluarga pun tidak harmonis lagi. Keadaan keluarga tidak utuh lagi seperti ini mengakibatkan anak kurang mendapatkan kasih sayang dari orang tua. ${ }^{18}$

Sesuai dengan pengertian dari keluarga quasi broken home, menurut Sudarsono, ciriciri keluarga yang dikatakan quasi broken home adalah sebagai berikut: ${ }^{19}$

${ }^{18}$ Gerungan, Psikologi Sosial, (Bandung PT. Eresco, 1988), h. 68.
1) Salah satu orang tua ataupun keduanya sering meninggalkan anak karena mencari nafkah.

2) Salah satu dari kedua orang tuanya atau keduanya tidak hadir secara continue dalam tenggang waktu yang relatif lama atau kesempatan dirumah sangat pendek.

3) Salah satu dari orang tua meninggalkan rumah tanpa berita (melarikan diri).

Dan menurut Gerungan, ciri-ciri keluarga yang dikatakan quasi broken home adalah sebagai berikut: ${ }^{20}$

1) Orang tua utuh, namun salah satu orang tua ataupun keduanya sering meninggalkan anak karena sibuk dengan tugas.

2) Orang tua tidak berada di rumah secara berulang-ulang dalam waktu yang relatif lama.

\section{Fenomena Quasi Broken Home}

Quasi broken home ialah apabila di dalam keluarga yang mana orang tua masih utuh, akan tetapi ayah dan ibu jarang pulang

\footnotetext{
${ }^{20}$ Gerungan, Psikologi..., h. 68.
} 
kerumah. Hal ini disebabkan tugas atau hal-hal lain sehingga harus meninggalkan anakanaknya dan hal ini terjadi secara berulangulang.

\section{Kondisi Perekonomian Keluarga Quasi}

\section{Broken Home}

a. Penghasilan Setiap Bulan

Setelah peneliti melakukan penelitian, ternyata diketahui bahwa keluarga pekebun tidak memiliki penghasilan yang tetap setiap bulannya. Seperti yang dikatakan oleh salah seorang informan ${ }^{21}$, bahwa penghasilan mereka perbulan tidak tetap, apalagi musim panen hanya satu tahun sekali. Jadi, hasil panen satu tahun itu di bagi perbulannya, sehingga penghasilan setiap bulan selalu berbeda.

Dari uraian diatas mengenai penghasilan perbulan, rata-rata keluarga yang berkebun tidak memiliki hasil yang tetap. Apalagi mereka panen hasil kebun hanya setahun sekali, adakalanya hasil panen itu melimpah dan adakalanya hasil panen itu gagal. Penghasilan yang didapat satu tahun itu dibagi untuk kebutuhan mereka perbulan. Biasanya sebelum musim panen, keluarga pekebun meminjam uang kepada pemilik toke untuk memenuhi kebutuhan sehari-hari.

b. Jumlah Penghasilan

21 Wawancara dengan Dwita Sari (anak dari ibu Rukini), 16 Januari 2018.
Jumlah penghasilan keluarga pekebun ada yang sama dan ada juga yang tidak. Hal ini dipengaruhi seberapa besar mereka meminjam uang kepada toke, karena semakin besar jumlah pinjaman mereka maka akan semakin kecil juga pendapatan mereka, sebab harus melunasi hutang terlebih dahulu. Seperti yang diungkapkan oleh salah seorang informan ${ }^{22}$ bahwa, penghasilan orang tuanya satu bulan lebih kurang 1.000.000. Itupun dipakai untuk melunasi-hutang-hutang mereka kepada toke. Senada dengan yang dikatakan oleh informan yang lain ${ }^{23}$ bahwa, penghasilan perbulan biasanya lebih kurang 1.000.000. Itu jika lagi tidak gagal panen, namun jika gagal panen, penghasilan hanya 250 hingga 500 ribu.

Jadi, hasil wawancara peneliti dengan informan mengenai jumlah penghasilan perbulan diketahui bahwa, ada sejumlah keluarga yang memiliki penghasilan sama dan ada juga keluarga yang mendapatkan hasil yang berbeda. jika hasil panen mereka banyak maka hasilnya bisa mencapai 15.000.000an pertahunnya, jadi lebih kurang 1.300.000 perbulan bagi mereka yang menggunakan pupuk. Namun, bagi mereka yang tidak menggunakan pupuk, penghasilan lebih kurang 1.000 .000 perbulan. akan tetapi, apabila mereka mengalami gagal panen, maka

22 Wawancara dengan Rahmad Ramadhan (anak dari ibu Mahainawati), 10 Januari 2018.

${ }^{23}$ Wawancara dengan Yedi Permadona (anak dari Bapak Bilir), 13 Januari 2018. 
AL-IMARAH: Jurnal Pemerintahan dan Politik Islam Vol. 3, No. 2, 2018

penghasilan bisa sangat menyusut sampai 300.000 perbulannya.

c. Pemenuhan Kebutuhan

Dengan tidak tetapnya penghasilan masyarakat pekebun, membuat mereka sulit untuk memenuhi kebutuhan sehari-hari. Namun, mereka masih bisa memenuhi kebutuhan pokok seperti makan dan minum. Ini dikarenakan banyaknya benntuk dan perbadaan kebutuhan masing-masing anggota keluarga. Seperti yang dikatakan oleh salah seorang informan ${ }^{24}$ bahwa kebutuhan mereka telah terpenuhi. Namun, tidak semuanya terpenuhi, karena kebutuhan keluarga sangat banyak dan berbeda. Tetapi walaupun sulit, kebutuhan pokok sudah dapat terpenuhi. Hal serupa juga dikatakan oleh informan yang lain ${ }^{25}$ bahwa, kebutuhan sehari-hari mereka sudah terpenuhi walaupun sulit. Namun, jika orang tua lagi panen biasanya memberikan uang lebih kepada anak-anaknya.

Dari uraian di atas mengenai pemenuhan kebutuhan, diketahui bahwa, ada sebagian keluarga yang kebutuhannya telah terpenuhi, walaupun harus meminjam uang kepada toke. Namun, ada pula yang kebutuhannya belum terpenuhi semua.

\section{Rentang Waktu Orang Tua di Kebun}

\footnotetext{
${ }^{24}$ Wawancara dengan Dwita Sari (anak dari ibu Rukini), 16 Januari 2018.

${ }^{25}$ Wawancara dengan Bella Permata (anak dari bapa Murlian Suhadi), 29 Januari 2018. 232
}

Dari hasil wawancara yang dilakukan peneliti, diketahui bahwa orang tua sangat jarang berada di rumah. Ini disebabkan masyarakat yang bekerja sebagai pekebun cenderung lebih sering berada di kebun daripada di rumah mereka. Seperti yang dikatakan oleh nara sumber ${ }^{26}$ bahwa, biasanya ketika orang tua sibuk, mulai dari memupuk sampai datang waktu panen, orang tua lebih sering berada di kebun. Adakalanya satu sampai dua bulan baru pulang, ada juga dua minggu sudah pulang. Namun, saat orang tua di rumah, biasanya orang tua mencari kesibukan lain seperti ke sawah atau menggarap sawah orang lain. Ini dilakukan orang tua untuk menambah penghasilan, jadi berada di rumah hanya pada malam hari.

\section{Ciri dan Penyebab Quasi Broken Home}

a. Orang Tua Sibuk Dengan Pekerjaan

Diketahui bahwa, masyarakat yang berkebun sangat sibuk karena pekerjaannya juga tidak mudah. Orang tua lebih sibuk dengan pekerjaannya dari pada meluangkan waktu untuk bersama anak-anak mereka. Seperti yang dikatan oleh salah seorang informan ${ }^{27}$ bahwa, Mereka berada di kebun bisa sampai berbulan-bulan apalagi kebun mereka yang terletak lebih jauh. Biasanya ketika orang tua belum sempat pulang, mereka menitipkan uang untuk anak-anak

\footnotetext{
${ }^{26}$ Wawancara dengan Bella Permata (anak dari Bapak Bihir), 29 Januari 2018.

${ }^{27}$ Wawancara dengan Hajri Efendi (anak dari ibu Desmanoti), 23 Januari 2018.
} 
mereka kepada tetangga yang kebunnya berada dekat dengan kebun mereka.

Dari uraian tersebut diketahui bahwa, masyarakat yang berkebun lebih sibuk untuk bekerja dari pada berada di rumah bersama anak-anak. Bisa sampai berbulan-bulan baru pulang ke rumah, itupun masih harus bekerja di sawah.

\section{b. Tidak Ada Waktu Luang}

Kesibukan yang dialami orang tua sangat berdampak pada, kurangnya waktu yang bisa diluangkan mereka bersama anak-anak. Padahal, anak masih sangat membutuhkan perhatian yang lebih dari kedua orang tua mereka. Seperti yang diungkapkan oleh narasumber ${ }^{28}$ bahwa, tidak ada waktu luang yang dimiliki orang tua, karena mereka sangat sibuk. Jika tidak berada di kebun, orang tua berada di sawah. Orang tua hanya berada di rumah pada malam hari. Namun, itu di gunakan untuk beristirahat. Senada dengan yang diungkapkan oleh informan yang lain ${ }^{29}$ bahwa, orang tua lebih sering tidak ada waktu untuk bersama meraka karena sibuk. Pekerjaan di kebun juga tidak bisa diselesaikan dalam satu atau dua hari.

Jadi, dari uraian di atas diketahui bahwa, tidak ada waktu yang diluangkan orang tua untuk anak-anak. Ini dikarenakan orang tua

\footnotetext{
${ }^{28}$ Wawancara dengan Yedi Permadona (anak dari bapak Bihir), 13 Januari 2018.

${ }^{29}$ Wawancara dengan Hajri Efendi (anak dari ibu Desmanoti), 23 Januari 2018.
}

sangat sibuk dengan pekerjaannya. Apa lagi orang tua yang berkebun, mereka lebih memerlukan banyak waktu untuk bermalam di kebun sembari menggarap kebun mereka.

c. Tidak Ada Waktu Untuk Membimbing Anak

Orang tua tidak memiliki waktu luang untuk anak-anaknya apalagi sampai harus membimbing mereka. Seperti yang diungkapkan oleh informan ${ }^{30}$ bahwa, tidak ada waktu yang dimiliki orang tua untuk membimbing anak, dalam hal belajar ataupun yang lainnya. Hal serupa juga diungkapkan oleh salah seorang informan ${ }^{31}$ bahwa, orang tua mereka jarang sekali, bahkan bisa dikatakan tidak pernah membimbing dalam belajar. Orang tua menilai bahwa bimbingan yang di dapat oleh anak di bangku sekolah itu sudah cukup untuk mereka. Hal ini juga dipertegas oleh narasumber yang lain ${ }^{32}$ bahwa, anak di sekolahkan untuk mendapatkan bimbingan dari sekolah. Orang tua menjadi lebih mudah dalam hal membimbing anak, karena sudah di bimbing oleh gurunya.

Dari uraian di atas diketahui bahwa, masyarakat yang berkebun tidak memiliki waktu untuk membimbing anak-anaknya

${ }^{30}$ Wawancara dengan Anggi Wansyah (anak dari ibu Serawiyah), 03 Februari 2018.

31 Wawancara dengan Dwita Sari (anak dari ibu Rukini), 10 Januari 2018.

${ }^{32}$ Wawancara dengan Rukini (orang tua Dwita Sari), 17 Januari 2018. 
AL-IMARAH: Jurnal Pemerintahan dan Politik Islam Vol. 3, No. 2, 2018

dalam hal belajar atau yang lainnya. Hal ini disebabkan oleh kesibukan orang tua untuk bekerja. Waktu yang dimiliki orang tua lebih banyak dihabiskan di kebun.

d. Orang Tua Meninggalkan Rumah Tanpa Berita

Ketika anggota keluarga memiliki kesibukan masing-masing, orang tua lebih sering berada di luar rumah. Tentu banyak sekali faktor yang membuat keluarga tidak harmonis. Salah satunya banyak masalah yang datang di dalam keluarga. Orang tua tidak bisa segera mengatasi karena kesibukkannya, hal ini membuat anak tidak ingin berbicara dengan orang tua dan akhirnya, orang tuapun meninggalkan rumah tanpa berita. Seperti yang diungkapkan oleh informan ${ }^{33}$ bahwa, memang jarang meninggalkan rumah tanpa berita. Namun, ketika hubungan antara anak dan orang tua sedang tidak baik, biasanya orang tua meninggalkan rumah tanpa berita. Karena percuma memberi tahu kepada anak jika anak tidak mau mendengarkan orang tua. Sama halnya dengan yang diungkapkan oleh narasumber yang lain ${ }^{34}$ bahwa, mereka jarang keluar atau pergi dari rumah tanpa berita. Namun, ketika ada masalah dengan anak-anak, anak menunjukkan muka masamnya dan tidak ingin berbicara dengan orang tua. Ini yang menyebabkan orang tua

\footnotetext{
33 Wawancara dengan Serawiyah (orang tua Anggi Wansyah), 04 Februari 2018.

${ }^{34}$ Wawancara dengan Mahainawati (orang tua Rahmad Ramadhan), 11 Januari 2018.

pergi atau keluar rumah tanpa berita. Hal ini didukung oleh ungkapan informan ${ }^{35}$ yang mengatakan bahwa, memang orang tua tidak selalu meninggalkan rumah tanpa sepengetahuan anak-anak. Tetapi ketika ada masalah di dalam keluarga, orang tua cenderung meninggalkan rumah tanpa sepengetahuan anak-anak. Ini mengakibatkan anakpun sering keluar rumah tanpa sepengetahuan orang tuanya.

Berdasarkan uraian di atas, diketahui bahwa adakalanya orang tua meninggalkan anak mereka tanpa sepengetahuan anak. Hal itu terjadi ketika didalam keluarga mereka sedang ada maslah. Namun, hal ini tidak begitu sering dilakukan oleh orang tua.

e. Orang Tua Berasumsi Bahwa Harta Adalah Sumber Kebahagiaan Utama

Dari wawancara yang peneliti lakukan kepada informan diketahui bahwa, orang tua berasumsi bahwa hartalah sumber kebahagian yang utama. Menurut mereka dengan harta semua kebutuhan akan dapat dipenuhi dengan begitu anak-anak mereka akan bahagia. Seperti yang diungkapkan oleh informan ${ }^{36}$ bahwa, harta adalah sumber utama untuk memberikan kebahagiaan kepada ana-anaknya. Dengan harta, semua kebutuhan akan dapat terpenuhi. Senada dengan yang diungkapkan oleh informan

\footnotetext{
${ }^{35}$ Wawancara dengan Hajri Efendi (anak dari ibu Desmanoti), 23 Januari 2018.

36 Wawancara dengan Desmanoti (orang tua Hajri Efendi), 27 Januari 2018.
} 
yang lain ${ }^{37}$ bahwa, memang benar harta bukanlah satu-satunya sumber kebahagiaan. Namun, bisa dikatakan bahwa harta adalah sumber utama karena ketika semua kebutuhan keluarga terpenuhi, pasti anakanak akan bahagia. Apalagi sekarang ini apapun membutuhkan uang. Namun, pernyataan yang diungkapkan oleh para orang tua sangat bertolak belakang dengan anak-anak mereka. Anak menganggap kasih sayang dan perhatian orang tua adalah sumber kebahagiaan utama. Seperti yang dikatakan oleh informan ${ }^{38}$ bahwa, harta bukanlah sumber utama untuk memberikan kebahagiaan. Sehingga anak menganggap, percuma jika harta melimpah namun kasih sayang yang diberikan orang tua selalu kurang. Hal serupa juga diungkapkan oleh informan lainnya ${ }^{39}$ bahwa, harta bukanlah satu-satunya sumber kebahagiaan. Kasih sayang dari orang tua itu lebih berharga dari segalanya, percuma jika harta banyak, apapun yang diinginkan selalu ada, tetapi tidak ada kasih sayang yang diberikan oleh orang tua.

Dari uraian yang peneliti paparkan di atas diketahui bahwa, Orang tua merasa bahwa hartalah yang utama untuk membuat anakanaknya bahagia. Menurut mereka, harta bisa memenuhi semua kebutuhan keluarganya,

37 Wawancara dengan Bihir (orang tua Yedi Permadona), 15 Januari 2018.

${ }^{38}$ Wawancara dengan Bella Permata (anak dari bapak Murlian Suhadi), 29 Januari 2018.

${ }^{39}$ Wawancara dengan Yedi Permadona (anak dari bapak Bihir), 13 Januari 2018. padahal tidak dengan kasih sayang dan kebersamaan diantara keluarga. Hal ini sangat bertentangan dengan anak-anak, mereka lebih memerlukan kasih sayang dan kebersamaan yang ada didalam keluarga dari pada harta.

f. Kurangnya Komunikasi Antara Anak dan Orang Tua

Komunikasi di antara anggota keluarga tidak selalu berjalan dengan baik. Ketika orang tua dan anak mengalami masalah didalam keluarga, komunikasi antara mereka akan berkurang. Bahkan hal itu dapat membuat anak semakin tidak ingin berkomunikasi dengan orang tuanya. Seperti yang diungkapkan oleh informan ${ }^{40}$ bahwa, adakalanya merasa jengkel dengan orang tua, akhirnya komunikasi antara mereka menjadi buruk. Sama halnya dengan yang diungkapkan oleh informan lain $^{41}$ bahwa, di dalam keluarga adakalanya terjadi pertengkaran antara anak dan orang tua. Pertengkaran ini sangat mempengaruhi komunikasi diantara mereka. Apalagi pertengkaran mereka terjadi bersamaan dengan orang tua yang akan bermalam di kebun, biasanya komunikasi diantara mereka tidak akan membaik sampai orang tua kembali lagi ke rumah. Namun, komunikasi antara anak dan orang tua juga akan menjadi baik saat anak menginginkan sesuatu dari orang tuanya. Seperti yang

40 Wawancara dengan Rahmad Ramadhan (anak dari ibu Mahainawati), 10 Januari 2018.

${ }^{41}$ Wawancara dengan Bella Permata (anak dari bapak Murlian Suhadi), 29 Januari 2018. 
dikatakan oleh bapak informan ${ }^{42}$ bahwa, komunikasi antara anak dan orang tua akan berjalan dengan baik ketika, anak menginginkan sesuatu dari orang tuanya.

Jadi, dapat diketahui bahwa, Ketika orang tua dan anak mengalami masalah didalam keluarga, komunikasi antara mereka akan berkurang. Adakalanya komunikasi diantara mereka baik, namun adakalanya tidak. Apalagi saat masalah tersebut datang bersamaan dengan orang tua yang akan pergi bermalam ke kebun, maka komunikasi antara mereka akan selalu buruk sampai orang tua pulang lagi ke rumah.

\section{Kualitas Kedekatan Anggota Keluarga}

Berdasarkan data yang didapat oleh peneliti diketahui bahwa, semakin anak bertambah dewasa, semakin malu untuk sekedar bersalaman atau bahkan memeluk orang tua mereka ketika pulang atau pergi dari rumah. Ini mempengaruhi kualitas kedekatan antara anak dan orang tua. Hal ini membuat jarak antara anak dan orang tua. Seperti yang dikatakan oleh seorang informan ${ }^{43}$ bahwa, ketika anak akan pergi atau pulang ke rumah, mereka tidak pernah bersalaman dan mencium tangan orang tua. Apalagi sampai memeluk orang tua mereka. Mereka merasa malu untuk melakukan hal tersebut. Anak merasa malu ketika harus bersalaman atau bahkan memeluk orang tuanya. Ini mengakibatkan terciptanya

\footnotetext{
${ }^{42}$ Wawancara dengan Bihir (orang tua Yedi Permadona), 15 Januari 2018.

${ }^{43}$ Wawancara dengan Yedi Permadona (anak dari Bapak Bihir), 13 Januari 2018.

jarak antara orang tua dan anak. Anak lebih memilih dekat dengan teman bergaul mereka daripada orang tua, bahkan orang tua tidak mengetahui dengan siapa saja anak mereka bergaul.

Jadi, hasil wawancara peneliti mengenai kualitas kedekatan anggota keluarga diketahui bahwa, anak tidak pernah bersalaman dan mencium tangan orang tuanya, apalagi sampai memeluk. Kalaupun ada, itu ketika anak sedang menginginkan sesuatu. Biasanya ketika anak pulang atau akan pergi ke luar rumah mereka hanya berpamitan kepada orang tua mereka. Ini yang menyebabkan jauhnya hubungan antara anak dan orang tua. Sehingga tercipta jarak antara anak dan orang tua.

\section{Dampak Quasi Broken Home Pada Perilaku Anak}

1. Pulang Larut Malam

Anak yang orang tuanya utuh, namun lebih sering berada di luar rumah untuk bekerja, cenderung mencari kesibukan sendiri di luar rumah. Diantaranya, anak lebih sering menghabiskan waktu bersama teman-teman di luar rumah. anak sering lupa waktu ketika berkumpul dengan teman-teman sehingga pulang larut malam. ini dilakukan mereka untuk mengurangi rasa kesepian saat berada di rumah.

\section{Bolos Sekolah}


Seringnya anak ditinggal orang tua untuk bekerja. Hal ini menyebabkan anak sering pulang larut malam. Akibatnya, anak bangun kesiangan serta bermalas-malasan untuk pergi ke sekolah. Orang tua juga tidak di rumah untuk membantu membangunkan ketika sudah pagi. Bahkan anak juga berani untuk bolos dari sekolah karena lebih memilih menghabiskan waktu bersama teman-temannya. anak yang sering ditinggal orang tuanya bermalam di kebun kerap kali membolos dari sekolah. Ini dikarenakan, anak lebih bahagia ketika bersama teman-teman mereka. Biasanya ketika anak bersama dengan teman-teman, anak sampai lupa waktu untuk pulang ke rumah. Akhirnya anak sering begadang bersama teman-temannya. Hal ini mengakibatkan anak seing kesiangan untuk pergi ke sekolah dan memilih untuk tidak sekolah.

\section{Perkelahian}

Anak yang emosinya belum bisa dikendalikan sangat mudah untuk mengeluarkan emosinya. Apalagi anak yang termasuk pada umur remaja awal, seharusnya mereka masih dalam pengawasan orang tua. Namun, ketika orang tua sibuk dengan pekerjaannya dan lebih sering berada di kebun. Hal ini menyebabkan anak menghadapi sendiri semua permasalahan yang muncul. Anak lebih memilih untuk berkelahi dengan saudara, teman bahkan tetangga mereka.

\section{Membantah orang tua}

Anak yang terlalu sering ditinggal orang tua bermalam di kebun, menjadikannya bergaul dengan siapa saja dan dapat mempengaruhi perilakunya. Sehingga anak lebih sering membantah ketika dinasihati oleh orang tua.

\section{Mabuk-mabukan}

Pergaulan anak yang sulit untuk diawasi orang tua karena sibuknya pekerjaan yang mereka lakukan membuat anak mereka menjadi menyimpang. Penyimpangan ini mulai terlihat dari kebiasaan anak mengkonsumsi lem untuk mendapatkan ketenangan.

Jadi dari uraian peneliti diatas dapat diketahui bahwa, banyak dampak negatif yang dialami remaja akibat kesibukan orang tua yang tidak memiliki waktu untuk mengawasi anak-anaknya. Orang tua terlalu sering meninggalkan anak di rumah, sehingga kurangnya perhatian dan waktu untuk membimbing, menasihati bahkan untuk sekedar berbagi cerita atau makan bersama anak-anak mereka. Dengan begitu akhirnya perilaku anak menjadi tidak baik. 
AL-IMARAH: Jurnal Pemerintahan dan Politik Islam

Vol. 3, No. 2, 2018

\section{Penutup}

\section{Kesimpulan}

Fenomena quasi broken home dalam keluarga pekebun dapat dilihat bahwa, keluarga ini menyerupai keluarga Broken Home, dimana hubungan antara orang tua dan anak tidak berjalan dengan baik. Namun, orang tua masih utuh. Di samping itu, orang tua lebih sering meninggalkan anak. Hal ini disebabkan oleh beberapa faktor yaitu orang tua sibuk dengan pekerjaan sehingga tidak memiliki waktu luang dan waktu untuk membimbing anak. Adakalanya quasi broken home disebabkan oleh orang tua meninggalkan anak tanpa berita. Disamping itu, orang tua berasumsi bahwa, harta merupakan faktor utama yang membuat anak bahagia. Dengan sibuknya orang tua, membuat komunikasi diantara mereka tidak berjalan dengan baik. Sehingga, menyebabkan kurang baiknya etika anak kepada orang tua. Dengan begitu, anak menjadi lebih dekat dengan teman pergaulannya dari pada dengan orang tua. Bahkan orang tuapun tidak mengetahui dengan siapa saja anak bergaul. Dampak quasi broken home pada perilaku anak yaitu: anak sering pulang larut malam, bolos sekolah, berkelahi, membantah orang tua bahkan sampai mabukmabukan.

\section{Saran}

Adapun saran-saran yang dapat diajukan oleh peneliti melalui tulisan ini, berdasarkan hasil penelitian dan pengamatan peneliti, peneliti menyarankan kepada beberapa pihak, yaitu:

a. Untuk orang tua, hendaknya lebih pandai membagi waktu antara kesibukan dan waktu yang diberikan untuk anak-anaknya, sehingga dapat meluangkan waktu yang cukup kepada anak agar anak tidak merasa dikucilkan dan dapat berkembang dengan baik sesuai dengan tahap perkembangannya.

b. Untuk remaja, walaupun orang tua sibuk bekerja hendaknya bisa mengontrol diri agar tidak terjerumus kedalam pergaulan yang terlalu bebas yang dapat merugikan diri sendiri dan orang lain.

\section{Pustaka Acuan}

Notosoedirdjo, Moeljono, Latipun. Kesehatan Mental Konsep dan Penerapan. (Malang: Universitas Muhammadiyah, 2005)

Basri, Hasan, Keluarga Sakinah Tinjauan Psikologi dan Agama. (Yogyakarta: Pustaka Pelajar, 2004)

Fahmi, Musthafa, Kesehatan Jiwa dalam Keluarga, Sekolah, dan Masyarakat, (Jakarta: Bulan Bintang, 1977)

HD, Kaelany. Islam dan Aspek-Aspek Kemasyarakatan. (Jakarta: Bumi Aksara) 
Al-Faqi, Sobri Mersi. Solusi Problematika Rumah Tangga Modern. (Surabaya: Sukses Publishing)

Andarmoyo, Sulistiyo. Keperawatan Keluarga (Konsep Teori, Proses dan Praktik keperawatan). (Yogyakarta: Graha Ilmu)

Effendi, Nasrul, Dasar-dasar Keperawatan Kesehatan Masyarakat, (Jakarta: EGC, 1998)

Rifa'I, Muhammad. Sosiologi Pendidikan. (Jakarta: Ar-Ruzz Media)

Santrock, Life Span Defelopment. terjemahan oleh Juda Damanik, Ahmad Chusairi. (Jakarta: Erlangga 2002)

Sudarsono. 2008. Kenakalan Remaja. (Jakarta: PT. Rineka Cipta, 2008)

Atmasasmita, Romli, Problema Kenakalan Anak-anak atau Remaja. (Bandung: CV. Armico, 1984)

Fanani, Achmad. Kamus Populer InggrisIndonesia, Indonesia-Inggris. (Jogjakarta: Literindo)

Gerungan, Psikologi Sosial. (Bandung: PT. Eresco, 1988) 